\title{
Shelterwood cutting in a boreal mixedwood stand: 5-year effects of the final cut on development of aspen suckers and released conifers
}

\author{
by Marcel Prévost ${ }^{1 *}$ and Lise Charette ${ }^{1}$
}

\begin{abstract}
We used the two-step shelterwood cutting to release conifer advance growth and limit the development of trembling aspen (Populus tremuloïdes) suckers in a stratified mixed aspen - conifer stand. This study presents the effects of the final cut, applied 12 years after the establishment cut, on the 5-year response of advance regeneration and aspen sucker development. Suckering was inversely proportional to the intensity of the establishment cut, with 19000, 14900 and 6800 stems/ha two years after the final cut, respectively, in the initial removal of 35\%, 50\% and 65\% basal area. By year 5 however, the treatment effect on stem density was no longer significant due to high aspen mortality in the 35\% and 50\% cuts. At this time, the density of conifer stems taller than $100 \mathrm{~cm}$ was comparable to that of aspen stems in the $35 \%$ and $50 \%$ cuts, while conifers dominated the $65 \%$ cut. Standing mortality was higher for hardwood (22-28\%) than for conifer (4-9\%) advance growth, except in the uncut control (14\% and $9 \%$, respectively), while windthrow averaged $4 \%$ and $8 \%$, respectively, in the three partial cuts without being related to treatment. Small merchantable conifer stems (diameter at breast height - DBH 9.1-15.0 cm) that were retained were most affected by windthrow, but overall losses were found acceptable considering DBH and height growth of the surviving stems. This study confirms that the two-step shelterwood cutting that secures conifer advance regeneration should be considered to limit hardwood conversion in the boreal mixedwood forest.
\end{abstract}

Key words: ecosystem-based forest management; hardwood expansion; stratified species mixture; conifer advance growth; small merchantable stems

\section{RÉSUMÉ}

Nous avons utilisé la coupe progressive en deux phases afin de dégager la régénération résineuse préétablie et de limiter le drageonnement du peuplier faux-tremble (Populus tremuloïdes) dans un peuplement mixte stratifié de trembles et de conifères. Dans le présent article, nous présentons les effets de la coupe finale, appliquée 12 ans après la coupe d'établissement, sur le développement de la régénération préétablie et des drageons de tremble après 5 ans. Le drageonnement s'est révélé inversement proportionnel à l'intensité de la coupe d'établissement, avec 19000, 14900 et 6800 tiges/ha 2 ans après la coupe finale, respectivement, dans les prélèvements initiaux de 35,50 et $65 \%$ de la surface terrière. Cependant, dès l'année 5 , l'effet du traitement sur la densité des tiges n'était plus significatif, en raison du taux élevé de mortalité du tremble dans les coupes à 35 et à $50 \%$. La densité des tiges de conifères dépassant les $100 \mathrm{~cm}$ était alors comparable à celle des tiges de tremble dans les coupes à 35 et à $50 \%$, mais les conifères dominaient la coupe à $65 \%$. Le taux de mortalité sur pied était plus élevé pour les feuillus (22-28\%) que pour les conifères (4-9\%) préétablis, à l'exception du témoin non coupé (14 et $9 \%$, respectivement). Cependant, le chablis était respectivement de 4 et $8 \%$, en moyenne, dans les trois coupes partielles, et ce, sans lien au traitement. Les petites tiges marchandes de conifères (diamètre à hauteur de poitrine - DHP de 9,1-15,0 cm) qui avaient été retenues ont été les plus touchées par le chablis. Toutefois, les pertes globales ont été jugées acceptables, compte tenu de la croissance en DHP et en hauteur des tiges ayant survécu. Cette étude confirme que la coupe progressive en deux phases basée sur la régénération préétablie devrait être envisagée pour limiter l'enfeuillement en forêt mixte boréale.

Mots-clés : aménagement écosystémique; enfeuillement; mélange stratifié d'essences; régénération préétablie de conifères; petites tiges marchandes.

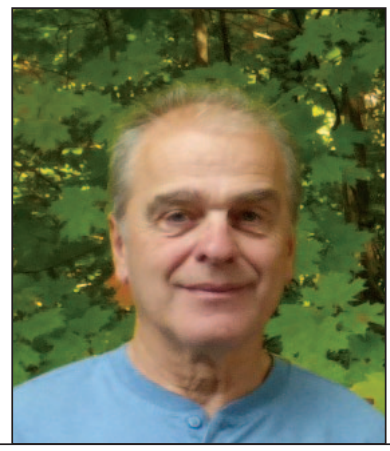

Marcel Prévost

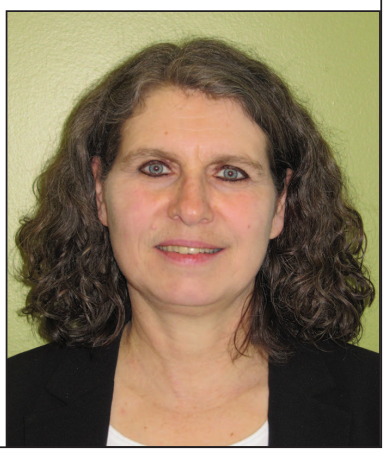

Lise Charette

\footnotetext{
${ }^{1}$ Ministère des Forêts, de la Faune et des Parcs du Québec, Direction de la recherche forestière, 2700 rue Einstein, Québec, QC, Canada G1P 3W8 ; *Corresponding author: marcel.prevost@mffp.gouv.qc.ca
} 


\section{Introduction}

The problem of hardwood expansion, (or invasion), which is the replacement of conifer species by broadleaved species across the landscape, is well recognized in the Canadian boreal mixedwood forest (Greene et al. 2002; Grondin et al. 2003; Laquerre et al. 2009). Shade-intolerant hardwoods, such as trembling aspen (Populus tremuloides Michx.) and paper birch (Betula papyrifera Marsh.), can occupy cutover sites to the detriment of conifers such as balsam fir (Abies balsamea (L.) Mill.), white spruce (Picea glauca (Moench) Voss) and black spruce (Picea mariana (Mill.) B.S.P.). For instance, in stands that contain aspen even in small proportions, management difficulties result from its root suckering ability and rapid early growth that is supported by the parent-tree root system, which gives it a strong advantage over conifers (Greene et al. 1999). Maintaining a conifer component to preserve natural species diversity is suitable at the stand level. Moreover, mixedwood stands may have greater productivity (Man and Lieffers 1999; Edgar and Burk 2001; MacPherson et al. 2001; Kabzems et al. 2007), increased resilience against insects and diseases (Su et al. 1996; Jactel et al. 2005) and a greater diversity of forest products (MacDonald 1995). Therefore, a sound silvicultural approach for mature aspen conifer mixtures should aim to modulate the establishment of the new cohort by limiting aspen development and promoting conifer species. Some silvicultural experiments have already shown that partial canopy removal can limit aspen development and accelerate the establishment and growth of shade-tolerant species in aspen - conifer mixtures (e.g., Prévost and Pothier 2003; Man et al. 2008; Groot et al. 2009).

The two-step shelterwood system can be used to create conditions that favour the establishment of a new cohort under a partial overstory (Matthews 1989; Nyland 2002). In this system, the establishment cut aims most often to promote natural seeding or can alternatively aim to release an advance regeneration stratum (Smith et al. 1997). The final cut (or removal cut) is usually applied 5-15 years later to remove the overstory and completely release the advance regeneration. The merit of the establishment cut mainly relies on establishing a new stand of desired species before the final cut, but growth and mortality of the residual cover must also be considered (e.g., Prévost et al. 2010; Urgenson et al. 2013). Furthermore, the advance regeneration response to the final cut must be evaluated for an overall assessment of the shelterwood system. While the establishment cut provides ideal shelter for the acclimation of advance regeneration and the establishment of new seedlings, the removal cut is often necessary to optimize growth (Smith et al. 1997).

We experimented with this system to accelerate natural succession in a stratified trembling aspen - conifer stand containing a dense advance conifer regeneration in Quebec, Canada. The establishment cut was carried out in 2001 and was successful in securing conifer regeneration and limiting aspen sucker development (Prévost and DeBlois 2014). As expected, light interception by the residual cover and the preserved advance growth was harmful to shade-intolerant aspen during the establishment phase. In addition to the silvicultural function of casting shade on emerging aspen suckers, the growth response of residual stems was another positive outcome (Prévost and Dumais 2014). The establishment cut permitted the harvesting of imminent aspen mortality and favoured conifer survival and recruitment to merchantable size (diameter at breast height $-\mathrm{DBH} \geq 9.1 \mathrm{~cm}$ ). In addition, the retention of small merchantable conifer stems (9.1-15.0 cm DBH) contributed substantially to basal area (BA) gains during the establishment phase.

The final cut was applied in the fall of 2013, 12 years after the establishment cut. At this time, the conifer advance regeneration was around 8- $\mathrm{m}$ in height, with some individuals reaching 10-m (Prévost and DeBlois 2014), and a complete release appeared to be timely. It was anticipated that these conifer saplings would respond to overstory removal and limit aspen development in the new stand. This paper presents the effects during the first five years after the final cut on the development of the second cohort of aspen suckers in relation to the response of conifer advance growth. We hypothesized that: (i) aspen suckering will be inversely proportional to the intensity of the first cut; (ii) the shade cast by the retained advance growth will limit aspen sucker development; and (iii) balsam fir will show a better growth response than spruce ( $P$. glauca or P. mariana) to the final cut (e.g., Prévost et al. 2016).

\section{Material and methods \\ Study site and experimental design}

The stand under study was located in the balsam fir - yellow birch bioclimatic domain (region 4d) in the High Hills of Charlevoix and Saguenay (Saucier et al. 2009), approximately $160 \mathrm{~km}$ northeast of Québec City, Quebec, Canada ( $47^{\circ} 55^{\prime} \mathrm{N}$, $70^{\circ} 03^{\prime} \mathrm{W}$ ). The initial merchantable BA of $26 \mathrm{~m}^{2} /$ ha was composed of $53 \%$ trembling aspen, $28 \%$ paper birch, $11 \%$ balsam fir, $3 \%$ white spruce, $2 \%$ black spruce and $2 \%$ red maple (Acer rubrum L.). Mature aspen of 80-90 years-of-age dominated the main canopy whereas conifers of $40-50$ years old generally occupied the intermediate layer. The density of advance conifer regeneration $\geq 1.3 \mathrm{~m}$ in height and $<9.1 \mathrm{~cm} \mathrm{DBH}$ was 1400 stems/ha and consisted primarily of balsam fir.

The experiment consisted of four complete randomized blocks, each one containing five treatments on $50 \mathrm{~m} \times 50 \mathrm{~m}$ experimental units: an uncut control (0\%), three partial cutting intensities (uniform removal of $35 \%, 50 \%$ and $65 \%$ of $\mathrm{BA}$ ), and a careful logging around advance growth removing $100 \%$ of merchantable hardwoods and conifers with $\mathrm{DBH}$ $\geq 15.1 \mathrm{~cm}$. For the conifer fraction (16\% of BA), this $100 \%$ cut roughly corresponds to a CPPTM (Coupe avec Protection des Petites Tiges Marchandes) in Quebec (Ruel et al. 2013) and to a HARP (Harvesting with Regeneration Protection) in Ontario (Groot et al. 2005). All small merchantable conifers $(9.1-15.0 \mathrm{~cm}$ in $\mathrm{DBH})$ were also retained in the three partial cuts, while the stems to be removed were selected in the following order: 1) aspen (which was almost mature); 2) birch or maple (the less vigorous of the two); 3) mature fir to avoid losses by windthrow; and 4) spruce (mature or declining only). This establishment cut was done in late summer 2001 using a chainsaw for felling. Trees were debranched and slashed on site, to be transported to the landings with a F4 Dion track forwarder from 50-m equidistant trails. The final (or removal) cut was carried out in the three partial cuts in the fall of 2013, 12 years after the first cut, protecting small merchantable conifers and using the same logging procedure. The stand and the experimental design are described in detail in Prévost and DeBlois (2014). 


\section{Vegetation monitoring}

Each experimental unit contained a $20 \mathrm{~m} \times 20 \mathrm{~m}$ central plot $\left(400 \mathrm{~m}^{2}\right)$ and sixteen $2 \mathrm{~m} \times 2 \mathrm{~m}$ quadrats $\left(4 \mathrm{~m}^{2}\right)$ for vegetation monitoring. After the first cut in 2001, all residual stems of commercial species $\geq 1.3 \mathrm{~m}$ in height were numbered in the $400-\mathrm{m}^{2}$ plot. Species, DBH, total height, crown height and four crown radii ( $\mathrm{N}, \mathrm{E}, \mathrm{S}$, and $\mathrm{W})$ were then recorded. These stems were surveyed at years 1, 2, 3, 5, 7 and 10 post-harvest during the establishment phase (Prévost and DeBlois 2014); those that survived to the final cut in 2013 were measured in 2014, 2015, 2016 and 2018 (years 1, 2, 3 and 5 post-removal). Species, DBH, total height and crown height were recorded. Meanwhile, the sixteen $4-\mathrm{m}^{2}$ quadrats were used to do postremoval regeneration surveys. Commercial species (balsam fir, black spruce, white spruce, trembling aspen, paper birch, red maple) and the principal non-commercial species, beaked hazel (Corylus cornuta Marsh.), mountain maple (Acer spicatum Lam.), striped maple (Acer pensylvanicum L.), mountain ash (Sorbus americana Marsh.) and willow (Salix spp.) were tallied by height class (1-5, 6-30, 31-60, 61-100, $101-200,201-300,>300 \mathrm{~cm}$ up to $9.0 \mathrm{~cm} \mathrm{DBH})$.

\section{Statistical analyses}

Regeneration density measured in 2011, two years before the final cut (2013), and at years 1, 2, 3 and 5 post-cut (20142016 and 2018) was analyzed separately by species for balsam fir, spruce (pooled white and black spruces), trembling aspen, paper birch, red maple, mountain maple, striped maple and beaked hazel. Linear mixed models with repeated measurements were used with a variance-covariance matrix to take into account the correlation between measurements that were performed on the same experimental units. The choice of this matrix was made using goodness-of-fit and parsimony criteria and took into account the unequal time intervals. Intensity of the establishment cut, measurement year and their interaction were introduced into the model as fixed-effect factors, whereas block was considered as a random effect. For significant interactions between main factors, levels of one factor were compared at a fixed level of the other factor. All regeneration data were transformed $(\sqrt{ } \mathrm{x})$ to improve homogeneity of variance. For commercial species, the density of saplings $\geq 1.3 \mathrm{~m}$ in height immediately after the establishment cut was tested as a covariate but was rejected in all cases.

The effects of cutting intensity and species (trembling aspen and conifers) on regeneration density among height classes (A: 6-100 cm, B: $101-200 \mathrm{~cm}, \mathrm{C}: 201-300 \mathrm{~cm}$ and D: $>300 \mathrm{~cm}$ ) were evaluated 1,2,3 and 5 years after the final cut using a classic four-way analysis of variance with establishment cut intensity, species and height class as fixed effects and block as a random effect. For this analysis, we conducted tests of simple effects (Winer 1971) using the triple interaction to make comparisons of interest within a third factor. We opted for this approach whether the triple interaction was significant (years 1, 2 and 3) or not (year 5), considering all main effects were significant (Iacobucci 2001). The cubic root transformation was used and values are presented in their original scale.

Height and DBH of pre-established conifers were analyzed with the same classic four-way analysis, 0 and five years after the final cut, except that height class was replaced by initial
DBH class (saplings: $\mathrm{DBH}<9.1 \mathrm{~cm}$, merchantable: $\mathrm{DBH}$ $\geq 9.1 \mathrm{~cm}$ ), based on the last measurement conducted in 2011, two years before the cut. We considered that stems with a $\mathrm{DBH} \geq 8.0 \mathrm{~cm}$ in 2011 would have recruited to merchantable size $(\mathrm{DBH} \geq 9.1 \mathrm{~cm})$ in two years (2013). For both height and $\mathrm{DBH}$, stem height measured immediately after the establishment cut was used as a covariate to account for possible differences prior to the treatment. This covariate was adjusted beforehand to take into account the different ranges of values in the two DBH classes (Milliken and Johnson 2002).

Data for mortality of pre-established stems were analyzed separately for standing mortality and windthrow, and for years 0 and 5 after the final cut, comparing two species groups (hardwoods = paper birch, red and sugar maples; conifers = balsam fir, black and white spruces). We used a three-way analysis of variance with establishment cut intensity and species group as fixed effects and block as a random effect. This analysis included all stems that were established prior to the first cut and still alive in 2011, two years before the final cut. The rate of mortality was expressed in \% $(100 \times$ number of dead stems at year 0 or 5 / number of live stems at year -2 ).

All analyses were performed on experimental unit values with the MIXED procedure of SAS (v. 9.4, SAS Institute Inc., Cary, North Carolina) for regeneration density, height and DBH of conifer advance regeneration, and with the GLIMMIX procedure for mortality data, the latter using the logit-link function and a binomial distribution. The Kenward-Roger method was used for approximating the denominator degrees of freedom. The statistical significance was based on $p<0.05$ for all analyses and tests. In all cases where a factor or an interaction was significant, the Westfall method was used to assess differences (Westfall 1997). The 0.05 error rate was applied within each fixed level of the main factors, as a separate-family approach (Westfall et al. 2011). Homogeneity of variances and normality were assessed on residuals using standard graphical methods, along with the Brown and Forsythe test (homogeneity) and the Shapiro-Wilk test (normality).

\section{Results}

\section{Regeneration dynamics}

Establishment cut intensity and time relative to the final cut interacted for the density of trembling aspen, paper birch and beaked hazel $>5 \mathrm{~cm}$ in height $(\mathrm{CI} \times \mathrm{T}, p \leq 0.005$, Table 1$)$. Aspen density was not different among cutting intensities two years before the final cut (310-4650 stems/ha, Fig. 1). However, an increase in density was observed one year after the final cut in the $35 \%, 50 \%$ and $65 \%$ cuts (all $p<0.001$, results of multiple comparison tests not presented in the table). As a result, at years 1, 2 and 3 post-cut, aspen density was higher in the 35\% (respectively 18700, 19000 and 15200 stems/ha) and $50 \%$ cuts $(12400,14900$ and 12600$)$ than in both the $100 \%$ cut (2900, 2400 and 2100) and control (3900, 800 and 1200, $p \leq 0.037)$. In addition, the density was higher in the $35 \%$ compared to the $65 \%$ cut at years 2 and 3 (respectively 6800 and 4800 stems/ha, $p \leq 0.052$ ). At year 5 , the treatment effect was no longer significant, since aspen density strongly decreased between years 3 and 5 in the $35 \%$ and $50 \%$ cuts $(p \leq 0.042)$. For paper birch, the $\mathrm{CI} \times \mathrm{T}$ interaction was related to density changes in the $35 \%$ cut, with an increase at year 1 post-cut (from 200 to 9900 stems/ha, not shown) and a decrease between years 3 and 5 (from 1700 to 300, $p \leq 0.044$ ). For 
Table 1. Analysis of variance and associated probabilities $(P>F)$ for regeneration density (stems $/ \mathrm{ha},>5 \mathrm{~cm}$ in height) related to establishment cut intensity (0\%,35\%,50\%, 65\% and 100\% basal area removal) and time relative to the final cut (two years before and 1, 2, 3 and 5 years after)

\begin{tabular}{|c|c|c|c|c|c|c|c|c|c|}
\hline $\begin{array}{l}\text { Source of } \\
\text { variation }\end{array}$ & $d f$ & Balsam fir & Spruce & $\begin{array}{l}\text { Trembling } \\
\text { aspen }\end{array}$ & Paper birch & Red maple & $\begin{array}{l}\text { Mountain } \\
\text { maple }\end{array}$ & $\begin{array}{c}\text { Striped } \\
\text { maple }\end{array}$ & $\begin{array}{c}\text { Beaked } \\
\text { hazel }\end{array}$ \\
\hline $\begin{array}{l}\text { Cutting } \\
\text { intensity }(\mathrm{CI})\end{array}$ & 4 & 0.241 & 0.490 & $<0.001$ & 0.119 & 0.230 & 0.531 & 0.286 & 0.012 \\
\hline Time $(\mathrm{T})$ & 4 & $<0.001$ & 0.005 & $<0.001$ & 0.002 & $<0.001$ & $<0.001$ & 0.002 & 0.001 \\
\hline $\mathrm{CI} \times \mathrm{T}$ & 16 & 0.422 & 0.800 & $<0.001$ & 0.005 & 0.265 & 0.197 & 0.342 & 0.001 \\
\hline
\end{tabular}

Note: $d f=$ degrees of freedom of the numerator. Denominator degrees of freedom according to Kenward-Roger: $\mathrm{CI}=11.5$ to 18.7 , $\mathrm{T}=12.0$ to 59.7 , CI $\times \mathrm{T}=17.9$ to 59.4 . Variance-covariance matrix: spatial power (balsam fir, spruce, trembling aspen, red maple, mountain maple), variance components (beaked hazel) and unstructured (paper birch, striped maple). Data were transformed for all species $(\sqrt{\mathrm{x}})$. Significant $p$-values are presented in boldface type.

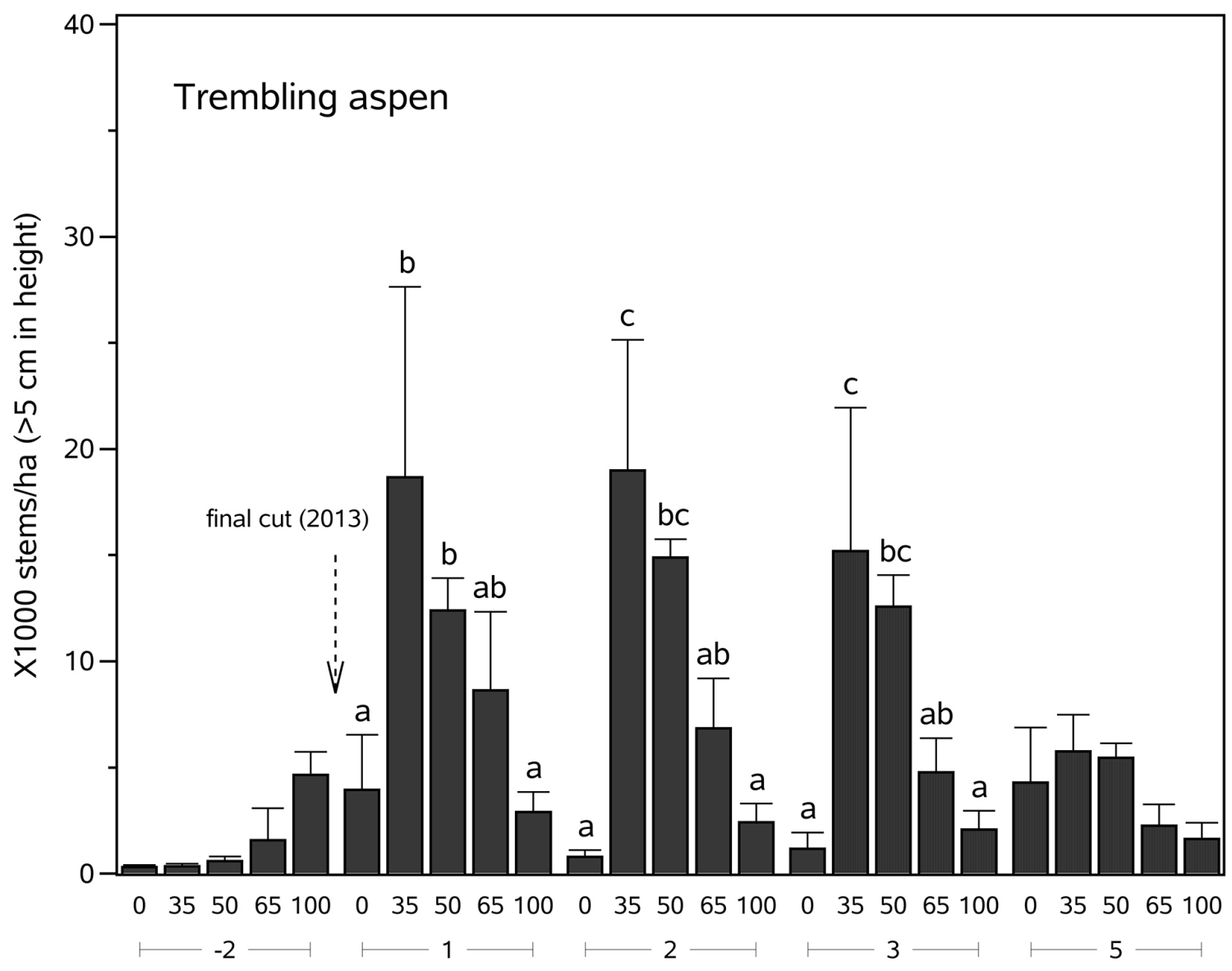

Years before or after the final cut

Fig. 1. Density of aspen suckers (stems/ha, $>5 \mathrm{~cm}$ in height) related to establishment cut intensity (0\%, 35\%, 50\%, 65\% and 100\% basal area removal), two years before and 1, 2, 3 and 5 years after the final cut of 2013. For each year, means associated with a different letter are statistically different $(p<0.05$, simulation-based adjusted $p$-values). Error bars represent the standard error of treatment means $(n=4)$. 
beaked hazel, the density was higher in the $100 \%$ cut (17700 stems/ha, not shown) than in the $65 \%$ cut (6000) before the final cut ( $p=0.019$ ) and at year 1 post-cut ( 15800 vs. 5800 , $p=0.052)$. In addition, beaked hazel density was higher in the $35 \%$ cut (15600 stems/ha) than in both the $65 \%$ cut and the control at year 5 (respectively 5100 and $6000, p \leq 0.027$ ).

A time effect was found for density of balsam fir, spruce, red maple, mountain maple and striped maple taller than $5 \mathrm{~cm}(p \leq 0.005$, Table 1, Fig. 2). The overall balsam fir density tended to increase between years 2 and 3 post-cut (from 20300 to 25000 stems/ha, $p=0.055)$ and significantly decreased between years 3 and 5 (to 17300, $p<0.001$ ). At a smaller scale, spruce density decreased from 600 to 400 stems/ha between years 3 and $5(p=0.047)$. For both mountain maple and striped maple, the density gradually decreased between years 1 (respectively 12000 and
3100 stems/ha), 2 (9400 and 1700) and 3 (5400 and 700, $p \leq 0.018)$ post-cut. A decrease from 14700 to 7900 stems/ha was also observed in years $2-3$ for red maple $(p<0.001)$. An increase was finally detected in years $3-5$ for red $(p=0.065)$ and striped maples $(p=0.002)$.

\section{Height classes of aspen vs. conifers}

Establishment cut intensity, species and height class all interacted for stem density $(\mathrm{CI} \times \mathrm{Sp} \times \mathrm{HC}, p \leq 0.003$, Table 2$)$ for the first three years after the final cut. Conifer density was generally higher than trembling aspen density (Table 3 ), in the control (years 1-3: all classes; year 5: A, D; $p \leq 0.061$ ), in the 65\% (year 1: all classes; years 2 and 3: A, D; year 5: A, C, $\mathrm{D} ; \mathrm{p} \leq 0.049)$ and $100 \%$ cuts (all years: A, B, C; $p \leq 0.054$ ) (200-23 000 vs. 0-7600 stems/ha). During the study, conifer density was also higher in some classes of the $35 \%$ (year 1: C,

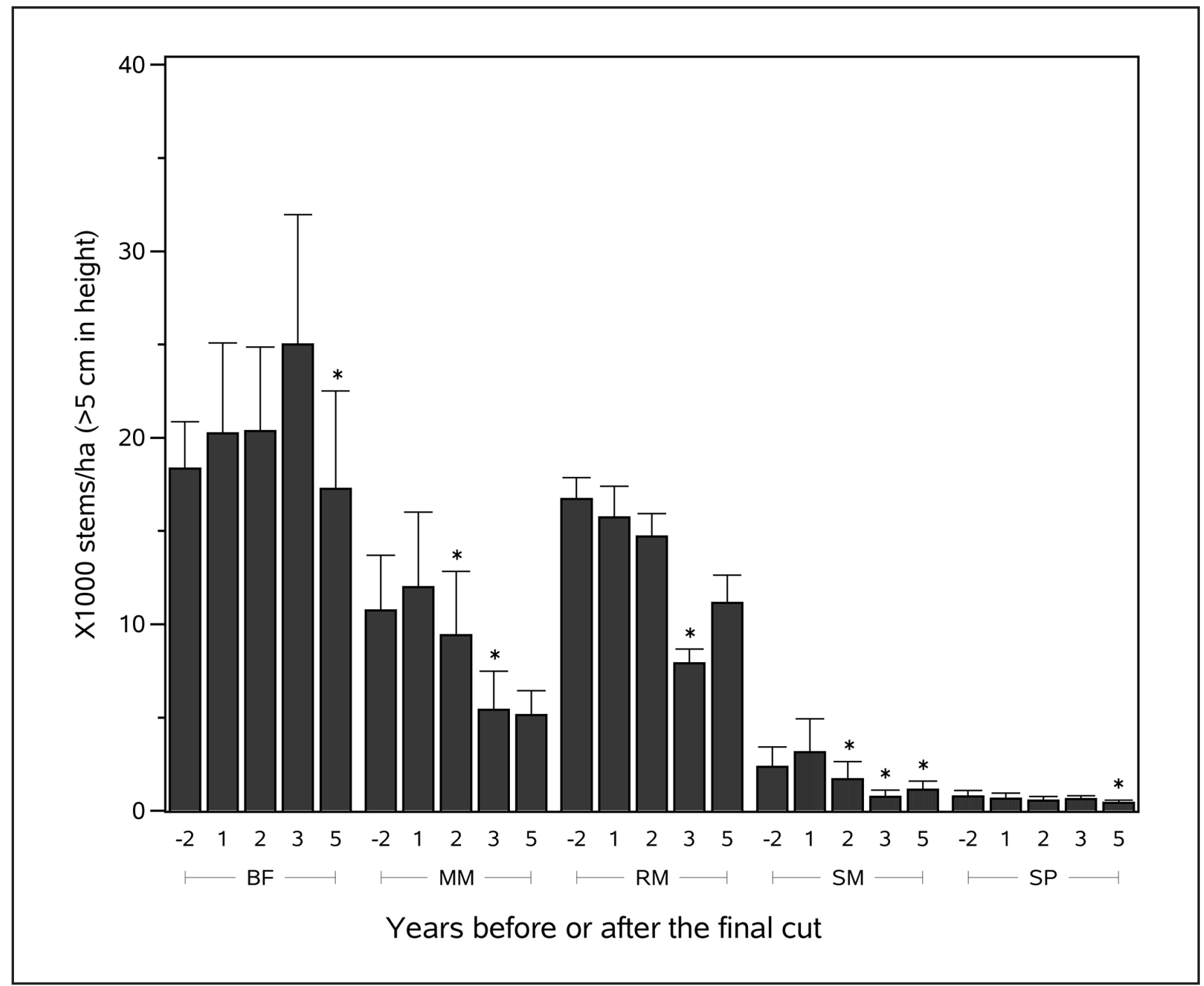

Fig. 2. Overall density of balsam fir (BF), mountain maple (MM), red maple (RM), striped maple (SM) and spruce (SP) regeneration (stems/ha, >5 cm in height) two years before and 1, 2, 3 and 5 years after the final cut of 2013. For each species, a mean associated with an * indicates a significant time effect with the preceding measurement year $(p<0.05$, simulation-based adjusted $p$-values]. Error bars represent the standard error of treatment means $(n=4)$. 
D; year 2: A, D; years 3 and 5: A; $p \leq 0.065)$ and $50 \%$ cuts (year 1: C, D; year 2: D; years 3 and 5: A; $p \leq 0.017$ ) (50036500 vs. $0-7600$ stems/ha). At years 2 and 3, however, aspen density was higher than conifer density in class B of both the $35 \%$ and $50 \%$ cuts (5700-9000 vs. $1100-1600$ stems/ha, $p \leq 0.015)$. A similar tendency was found in class $\mathrm{C}$ of the $35 \%$ cut at year 3 (2500 vs. 600 stems/ha, $p=0.066)$. At year 5 , classes B, C and D of the $35 \%$ and $50 \%$ cuts contained a comparable density of aspen (600-2100 stems/ha) and conifers (500-1500).

Table 2. Analysis of variance and associated probabilities $(\boldsymbol{P}>\mathrm{F})$ for regeneration density (stems/ha) related to establishment cut intensity $10 \%, 35 \%, 50 \%, 65 \%$ and $100 \%$ basal area removal), species (trembling aspen, conifers $)$ and height class $(A=6-100 \mathrm{~cm}, B=101-200 \mathrm{~cm}$, $C=201-300 \mathrm{~cm}, \mathrm{D}=>300 \mathrm{~cm}) 1,2,3$ and 5 years after the final cut

\begin{tabular}{lccccc}
\hline Source of variation & $d \boldsymbol{f}$ & Year $\mathbf{1}$ & Year $\mathbf{2}$ & Year $\mathbf{3}$ & Year 5 \\
\hline Cutting intensity (CI) & 4 & 0.063 & $<\mathbf{0 . 0 0 1}$ & $<\mathbf{0 . 0 0 1}$ & $\mathbf{0 . 0 0 2}$ \\
Species (Sp) & 1 & $<\mathbf{0 . 0 0 1}$ & $<\mathbf{0 . 0 0 1}$ & $<\mathbf{0 . 0 0 1}$ & $<\mathbf{0 . 0 0 1}$ \\
CI $\times$ Sp & 4 & $\mathbf{0 . 0 0 6}$ & $<\mathbf{0 . 0 0 1}$ & $<\mathbf{0 . 0 0 1}$ & $<\mathbf{0 . 0 0 1}$ \\
Height class (HC) & 3 & $<\mathbf{0 . 0 0 1}$ & $<\mathbf{0 . 0 0 1}$ & $<\mathbf{0 . 0 0 1}$ & $<\mathbf{0 . 0 0 1}$ \\
CI $\times$ HC & 12 & $<\mathbf{0 . 0 0 1}$ & $<\mathbf{0 . 0 0 1}$ & $<\mathbf{0 . 0 0 1}$ & $<\mathbf{0 . 0 0 1}$ \\
Sp $\times$ HC & 3 & 0.362 & $<\mathbf{0 . 0 0 1}$ & $<\mathbf{0 . 0 0 1}$ & $<\mathbf{0 . 0 0 1}$ \\
CI $\times$ Sp $\times$ HC & 12 & $<\mathbf{0 . 0 0 1}$ & $\mathbf{0 . 0 0 2}$ & $\mathbf{0 . 0 0 3}$ & 0.067 \\
\hline
\end{tabular}

Note: $d f=$ degrees of freedom of the numerator. Denominator degrees of freedom according to Kenward-Roger: $\mathrm{CI}=12$ to 120 , all other factors and interactions $=105$ to 120 . Analyses were done on the cubic root of regeneration density. Significant $p$-values are presented in boldface type.
Advance growth mortality

Immediately after the final cut (year 0), the rate of standing mortality was globally higher for hardwood (11\%) than conifer (2\%) advance growth (Sp, $p<0.001$, Table 4$)$. At year 5 post-cut, this was the case for all treatments (22-28\% vs. 4-9\%) except for the control ( $14 \%$ vs. $9 \%)(\mathrm{CI} \times \mathrm{Sp}, p=0.006)$. The rate of windthrow was not related to treatment, species group or year, with an average of $4 \%$ and $8 \%$, respectively for hardwoods and conifers, in the three partial cuts at year 5 .
Height and $\mathrm{DBH}$ of conifers related to $\mathrm{DBH}$ class At both measurement years, the cutting intensity and $\mathrm{DBH}$ class interacted for $\mathrm{DBH}$ and total height of pre-established conifer stems, balsam fir and spruce combined $(\mathrm{CI} \times \mathrm{DBHC}$, all $p<0.001$, Table 5, Fig. 3). In the sapling class, mean $\mathrm{DBH}$ was similar among treatments at years $0(5.3-6.3 \mathrm{~cm})$ and $5(5.8-7.6 \mathrm{~cm})$. In the merchantable class, the DBH was highest in the control, intermediate in the $100 \%$ cut and lowest in the partial cuts (respectively 14.2, 12.4 and $11.0-11.6 \mathrm{~cm}, p \leq 0.049$ ) at year 0 , and higher in the control than in the three partial cuts $(15.3 \mathrm{vs.}$ $13.3-14.0 \mathrm{~cm}, p \leq 0.016$ ) at year 5 . The height of conifer saplings was not related to treatment $(446-534 \mathrm{~cm})$ at year 0 but was higher in the $100 \%$ cut $(683 \mathrm{~cm})$ compared to the $0 \%, 35 \%$ and $65 \%$ cuts $(495-542 \mathrm{~cm}, p \leq 0.027)$ at year 5 . The height of merchantable conifers was higher in the control than in all other treatments for both years

Table 3. Density (stems/ha) of trembling aspen and conifer ( $97 \%$ balsam fir] regeneration by height class $(A=6-100 \mathrm{~cm}$, $B=101-200 \mathrm{~cm}, C=201-300 \mathrm{~cm}, \mathrm{D}=>300 \mathrm{~cm}$ ) related to establishment cut intensity [\% basal area removal] at years $1,2,3$ and 5 after the final cut

\begin{tabular}{|c|c|c|c|c|c|c|c|c|c|c|}
\hline \multirow{2}{*}{$\begin{array}{l}\text { Height } \\
\text { Class }\end{array}$} & \multicolumn{2}{|c|}{$0 \%$} & \multicolumn{2}{|c|}{$35 \%$} & \multicolumn{2}{|c|}{$50 \%$} & \multicolumn{2}{|c|}{$65 \%$} & \multicolumn{2}{|c|}{$100 \%$} \\
\hline & Aspen & Conifers & Aspen & Conifers & Aspen & Conifers & Aspen & Conifers & Aspen & Conifers \\
\hline \multicolumn{11}{|l|}{ Year 1} \\
\hline A & 3945 & 17031 & 17187 & 27539 & 11992 & 10078 & 7578 & 16094 & 0 & 12070 \\
\hline B & 0 & 586 & 1445 & 1328 & 352 & 1172 & 156 & 2305 & 78 & 4531 \\
\hline $\mathrm{C}$ & 0 & $195^{\star}$ & 0 & $469^{*}$ & 0 & 508 & 117 & 937 & 195 & 1641 \\
\hline $\mathrm{D}$ & 0 & 781 & 39 & 1172 & 39 & 742 & 781 & 1875 & 2617 & 3359 \\
\hline \multicolumn{11}{|l|}{ Year 2} \\
\hline A & 781 & 12969 & 7578 & 31055 & 8008 & 13555 & 3750 & 14570 & 39 & 11016 \\
\hline B & 0 & 508 & 8984 & 1562 & 5898 & 1211 & 2305 & 2383 & 78 & 4766 \\
\hline C & 0 & $234^{*}$ & 2148 & 469 & 937 & 469 & 117 & 898 & 195 & $1172^{\star}$ \\
\hline $\mathrm{D}$ & 0 & 703 & 273 & $1289^{*}$ & 39 & 742 & 664 & 1758 & 2109 & 3125 \\
\hline \multicolumn{11}{|l|}{ Year 3} \\
\hline A & 1172 & 18906 & 5117 & 36523 & 5625 & 16953 & 1719 & 23008 & $\mathbf{0}$ & 11406 \\
\hline B & 0 & 547 & 6875 & 1094 & 5742 & 1289 & 2070 & 2500 & 0 & 4687 \\
\hline C & 0 & $195^{\star}$ & 2500 & $586^{\star}$ & 937 & 469 & 273 & 1016 & 39 & 1523 \\
\hline $\mathrm{D}$ & 0 & 703 & 703 & 1250 & 273 & 625 & 703 & 1797 & 2031 & 3047 \\
\hline \multicolumn{11}{|l|}{ Year 5} \\
\hline A & 4023 & 13242 & 1563 & 26276 & 1883 & 9385 & 940 & 11930 & 78 & 7187 \\
\hline B & 273 & 664 & 1980 & 1238 & 2138 & 1506 & 643 & 2081 & 0 & 3984 \\
\hline $\mathrm{C}$ & 0 & 156 & 644 & 508 & 606 & 460 & 195 & 1021 & 0 & 1172 \\
\hline $\mathrm{D}$ & 0 & 703 & 1558 & 1269 & 829 & 782 & 469 & 1961 & 1562 & 2891 \\
\hline
\end{tabular}

Note: Means presented in boldface type are significantly different $(p<0.05)$ between aspen and conifers for a given height class within a cutting intensity.

${ }^{*}$ Indicates that a clear tendency for a difference was observed $(p \leq 0.066)$ 
Table 4. (A) Analysis of variance (ANOVA] related to establishment cut intensity $[0 \%, 35 \%, 50 \%, 65 \%$ and $100 \%$ basal area removal) and species group (hardwoods [H] or conifers [C]) immediately after (year 0 ) and 5 years after the final cut, and (B) Rate of standing mortality and windthrow

\begin{tabular}{lcccccr}
\hline (A) ANOVA $\boldsymbol{p}$ values & & \multicolumn{2}{c}{ Standing mortality } & & \multicolumn{2}{c}{ Windthrow } \\
\cline { 3 - 5 } Source of variation & $d f$ & Year 0 & Year 5 & & Year 0 & Year 5 \\
\hline Cutting intensity (CI) & 4 & 0.318 & 0.941 & 0.394 & 0.387 \\
Species group (Sp) & 1 & $<\mathbf{0 . 0 0 1}$ & $<\mathbf{0 . 0 0 1}$ & 0.824 & 0.837 \\
CI $\times$ Sp & 4 & 0.251 & $\mathbf{0 . 0 0 6}$ & 0.629 & 0.850 \\
\hline
\end{tabular}

(B) Rate of mortality

Standing mortality (\%)

Windthrow (\%)

\begin{tabular}{|c|c|c|c|c|c|c|c|c|}
\hline \multirow[t]{2}{*}{ Cutting intensity } & \multicolumn{2}{|c|}{ Year 0} & \multicolumn{2}{|c|}{ Year 5} & \multicolumn{2}{|c|}{ Year 0} & \multicolumn{2}{|c|}{ Year 5} \\
\hline & $\mathbf{H}$ & $\mathrm{C}$ & $\mathbf{H}$ & $\mathrm{C}$ & $\mathbf{H}$ & $\mathrm{C}$ & $\mathbf{H}$ & $\mathrm{C}$ \\
\hline $0 \%$ & 5 & 2 & 14 & 9 & 1 & 1 & 1 & 1 \\
\hline $35 \%$ & 9 & 5 & 22 & 8 & 4 & 4 & 4 & 5 \\
\hline $50 \%$ & 18 & 3 & 28 & 9 & 7 & 12 & 7 & 12 \\
\hline $65 \%$ & 15 & 1 & 26 & 4 & 1 & 5 & 1 & 7 \\
\hline $100 \%$ & 8 & 1 & 25 & 9 & 1 & 0 & 1 & 0 \\
\hline
\end{tabular}

Note: $d f=$ degrees of freedom of the numerator. Denominator degrees of freedom according to Kenward-Roger: $\mathrm{CI}=11.8$ to $14.9, \mathrm{Sp}$ and $\mathrm{CI} \times \mathrm{Sp}=30.0 . \mathrm{Significant} p$-values are presented in boldface type. Species groups: hardwoods = paper birch, red and sugar maples; conifers = balsam fir, black and white spruces

Table 5. Analysis of variance and associated probabilities $(P>F)$ for diameter at breast height $(D B H)$ and total height of preestablished conifers related to establishment cut intensity $(0 \%, 35 \%, 50 \%, 65 \%$, and $100 \%$ basal area removal), species (balsam fir or spruce) and DBH class (saplings [DBH $<9.1 \mathrm{~cm}$ ] or small merchantable stems [DBH $=9.1$ to $15.0 \mathrm{~cm}$ ]) immediately following the final cut (year 0 ) and 5 years after treatment

\begin{tabular}{|c|c|c|c|c|c|}
\hline \multirow[b]{2}{*}{ Source of variation } & \multirow[b]{2}{*}{$d f$} & \multicolumn{2}{|c|}{$\mathrm{DBH}$} & \multicolumn{2}{|c|}{ Total height } \\
\hline & & Year 0 & Year 5 & Year 0 & Year 5 \\
\hline Cutting intensity (CI) & 4 & $<0.001$ & 0.310 & $<0.001$ & $<0.001$ \\
\hline Species (Sp) & 1 & 0.005 & 0.014 & 0.166 & 0.292 \\
\hline $\mathrm{CI} \times \mathrm{Sp}$ & 4 & 0.467 & 0.632 & 0.167 & 0.276 \\
\hline DBH class (DBHC) & 1 & $<0.001$ & $<0.001$ & $<0.001$ & $<0.001$ \\
\hline $\mathrm{CI} \times \mathrm{DBHC}$ & 4 & $<0.001$ & $<0.001$ & $<0.001$ & $<0.001$ \\
\hline $\mathrm{Sp} \times \mathrm{DBHC}$ & 1 & 0.809 & 0.890 & 0.076 & 0.617 \\
\hline $\mathrm{CI} \times \mathrm{Sp} \times \mathrm{DBHC}$ & 4 & 0.791 & 0.727 & 0.854 & 0.790 \\
\hline Covariate & 1 & $<0.001$ & $<0.001$ & $<0.001$ & $<0.001$ \\
\hline
\end{tabular}

Note: $d f=$ degrees of freedom of the numerator. Denominator degrees of freedom according to Kenward-Roger: CI $=10.7$ to $11.7, \mathrm{Sp}, \mathrm{CI} \times \mathrm{Sp}, \mathrm{DBHC}, \mathrm{CI} \times \mathrm{DBHC}$, $\mathrm{Sp} \times \mathrm{DBHC}$ and $\mathrm{CI} \times \mathrm{Sp} \times \mathrm{DBHC}=40.3$ to 41.9 , and covariate $=53.0$ to 55.7. Significant $p$-values are presented in boldface type. Spruce includes black and white spruces.

0 (1094 vs. $812-886 \mathrm{~cm})$ and 5 (1213 vs. $929-1050 \mathrm{~cm}$, all $p<0.001)$, and was higher in the $100 \%$ cut $(1050 \mathrm{~cm})$ than in the $35 \%$ and $65 \%$ cuts (respectively 962 and $929 \mathrm{~cm}$, $p \leq 0.037)$ at year 5. Finally, for all treatments and DBH classes combined, spruce DBH was slightly higher than balsam fir DBH at years 0 (Lsmean $=9.0$ vs. $8.6 \mathrm{~cm})$ and $5(10.7$ vs. $10.2 \mathrm{~cm})(\mathrm{Sp}, p \leq 0.014$, Table 5, Fig. 3).

\section{Discussion}

The density of aspen regeneration was relatively low 10 years after the establishment cut (year-2) and, as expected, the final cut triggered aspen suckering (Fig. 1). This effect was proportional to the number of aspen stems that were initially left standing and harvested 12 years later, i.e., inversely proportional to the intensity of the establishment cut, which confirms our first hypothesis. As a whole, the first-year density of suckers was lower than the density of 15000-29000 stems/ha observed after the first cut (Prévost and DeBlois 2014). Our initial BA removal of 35\% resulted in comparable suckering following the first (15400 stems/ha) and final cuts (18700). However, the priority harvesting of aspen accelerated suckering in higher BA removals, with two and three times more suckers after the first cut than after the final cut in the 50\% (23400 vs. $12400 \mathrm{stems} / \mathrm{ha}$ ) and $65 \%$ cuts ( 29200 vs. 8600 ). Therefore, the first cut removed much of the aspen suckering potential in these two-step scenarios. In this context, the two-step shelterwood cutting approach provides an opportunity to influence the distribution of this vegetative reproduction between the establishment cut and the final cut, contrary to the clearcut which affects all aspen root systems at the same time. 


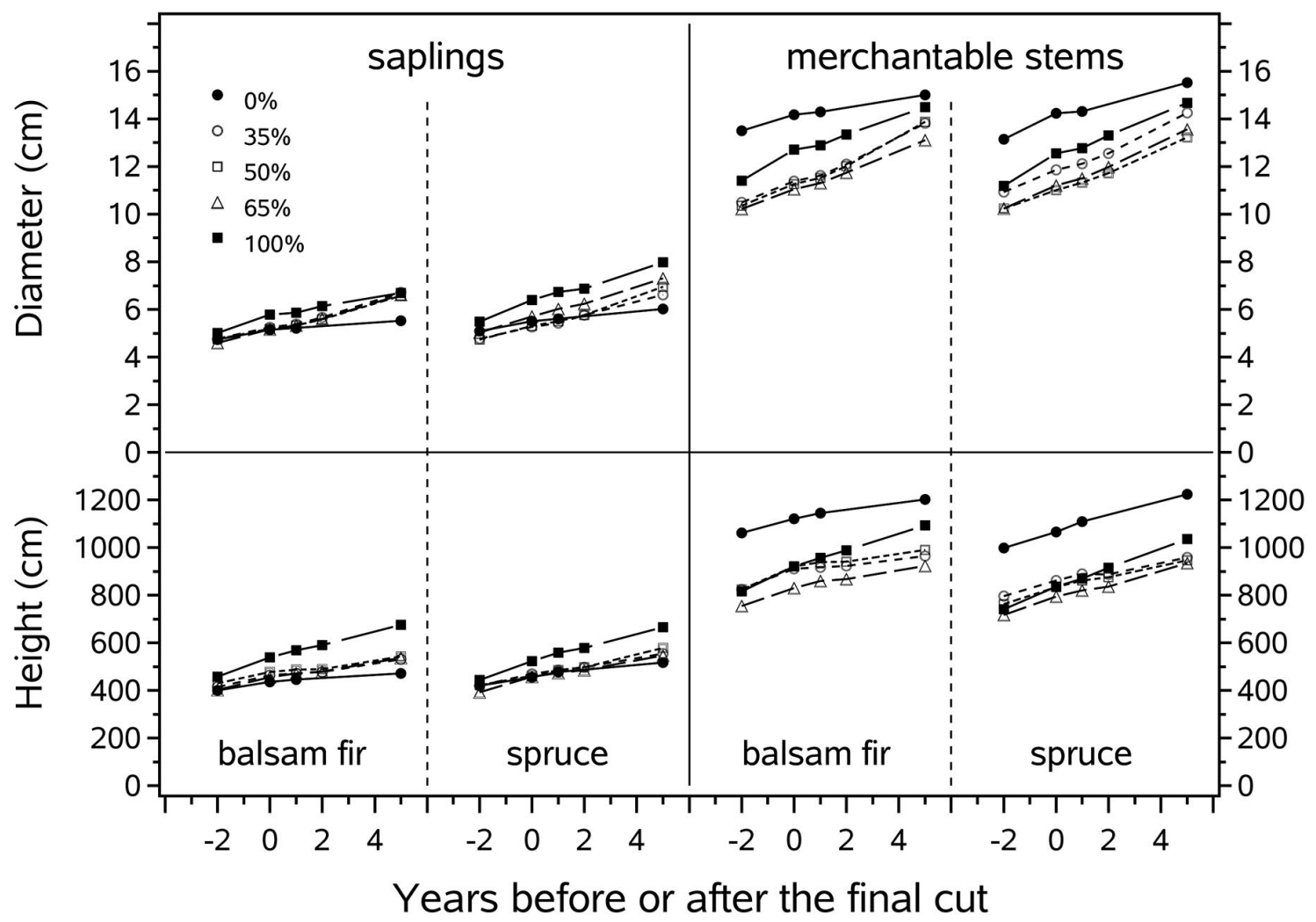

Fig. 3. $\mathrm{DBH}$ and total height related to species and establishment cut intensity $(0 \%, 35 \%, 50 \%, 65 \%$ and $100 \%$ basal area removal) two years before and 1, 2, 3 and 5 years after the final cut of 2013.

The analysis of stem density by height classes showed that conifers outnumbered aspen in all classes of the control and up to $300 \mathrm{~cm}$ in height in the $100 \%$ cut (Table 3 ). In the twostep scenarios, the final cut impacted regeneration dynamics in the $35 \%$ and $50 \%$ initial BA removals, while the effect was less pronounced in the 65\% BA removal. From year 2, aspen outnumbered conifers in the 100-200 cm class of the $35 \%$ and $50 \%$ cuts, and in the $200-300 \mathrm{~cm}$ class of the $35 \%$ cut. As with the establishment cut (Prévost and DeBlois 2014), the driving factor was the hormonal imbalance in the root system (Schier 1973). However, this effect was transient, since the densities of aspen and conifers taller than $100 \mathrm{~cm}$ were similar by year 5 , which indicates limited aspen recruitment in taller classes. At this time, conifers dominated the three taller classes in the $65 \%$ cut, unlike in the $35 \%$ and $50 \%$ cuts. Therefore, the first cut removing $65 \%$ of BA provided the best control of aspen five years after final removal. Future recruitment of aspen in taller classes of the two lowest BA removals will indicate the best scenario in relation to species composition of the new cohort. In comparison, aspen made up about one third of the taller stems in the $100 \%$ cut applied 17 years earlier (Table 3). The use of the CPPTM approach in the presence of dense conifer regeneration permitted the mainte- nance of a good proportion of conifers in the new cohort, which should persist in the long term.

Aspen is very intolerant to shade and requires full sunlight to thrive (Perala 1990). Survival of suckers was particularly restricted between years 3 and 5 after the final overstory removal, with mortality rates of $50-60 \%$ in two years (Fig. 1). Although self-thinning may have contributed, this high mortality confirms our second hypothesis of a detrimental shading effect from the tall conifer advance growth. Retention of small merchantable conifers certainly contributed to limiting light availability for taller aspen stems, especially because of their sustained height growth following the final cut (Fig. 3), which supports this practice as a basic strategy to limit hardwood expansion.

After five years, all treatments contained comparable densities of aspen, including the control, where significant suckering occurred in years 3-5 (Fig. 1). Such suckering was described by Schier and Smith (1979) as a normal and regular phenomenon in uncut aspen clones. In the present study, most residual aspens were near- to over-mature trees (Pothier et al. 2004). Field observations revealed that both standing mortality and windthrow of a few aspen stems caused the suckering observed in the control. This confirms that the first 
cut was successful in harvesting the dying aspens (Prévost and Dumais 2014), as observed in a comparable stand of the Lower Appalachians (Prévost et al. 2010).

The use of partial cutting in this study to secure the conifer advance growth raises the issue of windthrow hazards (e.g., MacDonald and Thompson 2003; Ruel et al. 2003). For instance, dispersal of residual trees, shallow-rooting and topographical exposure may lead to significant wind damage (Ruel et al. 2000; Lavoie et al. 2012; Mitchell 2013). However, in the species mixture under study, almost all mortality during the establishment phase occurred gradually on standing trees, particularly through aspen senescence in the $35 \%$ cut and paper birch decadence in the 65\% cut (Prévost and Dumais 2014). Standing mortality was also gradual for both species groups after the final cut (Table 4) and evenly distributed across the site. This form of mortality was responsible for $90 \%$ of hardwood losses, with red maple being the most affected pre-established species, particularly in years 2-3 (Fig. 2). Sudden exposure to open conditions may have imposed physiological stress and induced mortality (Bladon et al. 2006; Busby et al. 2006; Lavoie et al. 2012). It is worth mentioning that red maple was of low quality and vigour, being at its northern limit close to the $48^{\text {th }}$ parallel where the experiment was conducted. As reported following the establishment phase (Prévost and Dumais 2014), borderline ecological conditions may have limited the ability of red maple saplings to respond to the final release. Data also suggest that stressful open conditions may have contributed to the low survival of paper birch that established rapidly after the final cut, while beaked hazel captured a part of the growing space through vegetative reproduction (Tappeiner 1971).

Unlike hardwoods, conifers were equally affected by standing mortality and windthrow in the three partial cutting intensities (Table 4). While standing mortality was gradual, most windthrow occurred early after the final cut between late fall 2013 and June 2014 and in two groups of contiguous experimental units. As these units were located on the upper slope of forwarding trails connected to the two landings, we believe that wind was funneled from adjacent open areas (see Ruel et al. 2003). Therefore, the topographical exposure and trail network interacted for wind damage in this experiment which was conducted in the High Hills of Charlevoix. More precisely, the timing of extreme winds relative to the final harvest was probably the driving factor in windthrow (see Mitchell 2013).

Our finding that windthrow may affect a part of the released advance growth after the shelterwood system final cut merits further consideration. As observed in other studies (e.g., Thorpe et al. 2008; MacIsaac and Krygier 2009), most windthrow occurred in the first years after the final cut, and after five years the critical period should be over. According to Riopel et al. (2010), potential losses are a major constraint to widespread application of harvesting with protection of small merchantable stems in coniferous forests. These authors suggested considering the low merchantable value of the lost stems $(\mathrm{DBH} \leq 15.0 \mathrm{~cm})$ and the potential long-term gains of surviving stems to assess acceptability of these losses. Although small merchantable conifers were the most affected in this study, the global rates under $10 \%$ appear to be acceptable (Table 4), considering the $\mathrm{DBH}$ and height growth gains observed for the live stems (Fig. 3). We conclude that reten- tion of small merchantable conifers will certainly contribute to shorten the rotation period in this stand.

Balsam fir is known to have a greater ability than spruce to respond to release (Davis 1989). However, patterns of height and $\mathrm{DBH}$ of conifers after the final cut did not confirm our third hypothesis concerning a stronger growth response in balsam fir compared to spruce (Fig. 3). Conversely, there is a clear indication that spruce was able to compete with balsam fir although the significant DBH advantage of 5\% for spruce was marginal in biological terms. This is an interesting result because maintaining the spruce component of the boreal mixedwood stands is an important issue. Furthermore, the analysis of conifer height for two DBH classes confirms the ability of small merchantable stems to capture the growing space and maintain a dominant position following the final cut (Pothier et al. 1995).

\section{Management implications}

Within the wider framework of this study, it was previously shown that the establishment cut of a two-step shelterwood system can limit aspen regeneration in an aspen-dominated mixedwood stand presenting a dense conifer regeneration. However, to evaluate the overall merit of the two-step shelterwood system based on advance growth, it was necessary to assess the effects of the final cut. Although a 5-year period may be short to draw solid conclusions, relevant guidelines can be established. The establishment cut was successful in limiting aspen development up to $65 \%$ BA removal. Results indicate that, despite some paper birch decadence during the establishment phase, this high intensity cut allowed removal of most of the suckering potential prior to the final cut, while increasing conifer growth, and in turn, led to the best aspen control in the first years after the final cut. Therefore, removing up to two-thirds BA and as much aspen as possible in the establishment cut would be recommended to permit a greater proportion of conifers to be maintained in the new stand. Long-term observations will indicate how the harvesting intensity in each step may affect stand dynamics, composition and structural development. As for the $100 \%$ cut, conifers made up two thirds of stem density in the taller class after 17 years, and this proportion should persist in the future. This supports a previous conclusion (Prévost and DeBlois 2014) that small patch-clearcuts would alternatively permit the maintenance of a proportion of conifers in the presence of a dense advance regeneration.

The protection of conifer advance growth during both the establishment and final cuts was very important to confer a competitive advantage over aspen suckers. Retention of small merchantable conifers contributed to aspen decline and rapid site occupancy by conifers. Although some of the larger stems were blown down during an extreme wind event after the final cut, the overall losses remained acceptable. Nevertheless, it might be appropriate to harvest all merchantable stems during the final cut on sites with a high risk of windthrow.

\section{Acknowledgements}

We thank Daniel Dumais and Patricia Raymond for revising an earlier version of this manuscript, and Carole Coursolle for English language editing assistance. The Associate Editor and two anonymous reviewers are also acknowledged for their helpful comments. The authors are also indebted to 
Coop Quatre Temps, Abitibi-Consolidated Inc. (Resolute Forest Products) and the regional staff of the Ministère des Forêts, de la Faune et des Parcs du Québec (MFFPQ) for their excellent collaboration at different stages of this study. Heartfelt thanks are extended to Jean-Pierre Lapointe, Maurice Gagnon, Julie Forgues, Carlo Gros-Louis, Daniel Guimond, Serge Williams, Pascal Lainé, Étienne Du Berger, Christian Villeneuve and many summer students for their excellent fieldwork over the years. This study is part of Project 142332016 of the Direction de la recherche forestière, MFFPQ.

\section{References}

Bladon, K.D., U. Silins, S.M. Landhäusser and V.J. Lieffers. 2006. Differential transpiration by three boreal tree species in response to increased evaporative demand after variable retention harvesting. Agric. For. Met. 138: 104-119.

Busby, P.E., P. Alder, T.L. Warren and F.J. Swanson. 2006. Fate of live trees retained in forest cutting units, western Cascade Range, Oregon. Can. J. For. Res. 36: 2550-2560.

Davis, W.C. 1989. The role of released advance growth in the development of spruce-fir stands in eastern Maine. PhD Diss., Yale Univ., New Heaven, CT.

Edgar, C.B. and T.E. Burk. 2001. Productivity of aspen forests in northeastern Minnesota, U.S.A., as related to stand composition and canopy structure. Can. J. For. Res. 31: 1019-1029.

Greene, D.F., J.C. Zasada, L. Sirois, D. Kneeshaw, H. Morin, I. Charron and M.-J. Simard. 1999. A review of the regeneration dynamics of North American boreal forest tree species. Can. J. For. Res. 29: 824-839.

Greene, D.F., D.D. Kneeshaw, C. Messier, V. Lieffers, D. Cormier, R. Doucet, K.D. Coates, A. Groot, G. Glover and C. Calogeropoulos. 2002. Modelling silvicultural alternatives for conifer regeneration in boreal mixedwood stands (aspen/white spruce/balsam fir). For. Chron. 78: 281-295.

Grondin, P., L. Bélanger, V. Roy, J. Noël and D. Hotte. 2003. Envahissement des parterres de coupe par les feuillus de lumière (enfeuillement). In: P. Grondin and A. Cimon (Coord.). Les enjeux de biodiversité relatifs à la composition forestière. pp. 131-174. Ministère des Ressources naturelles, de la Faune et des Parcs, Direction de la recherche forestière et Direction de l'environnement forestier.

Groot, A., R. Man and J. Wood. 2009. Spatial and temporal patterns of Populus tremuloides regeneration in small forest openings in northern Ontario. For. Chron. 85: 548-557.

Groot, A., J.-M. Lussier, A.K. Mitchell and D.A. MacIsaac. 2005. A silvicultural systems perspective on changing Canadian forestry practices. For. Chron. 81: 50-55.

Iacobucci, D. 2001. Journal of Consumer Psychology's Special Issue on Methodological and Statistical Concerns of the Experimental Behavioral Researcher. J. Consum. Psychol. 10: 5-35.

Jactel, H., E. Brockerhoff and P. Duelli. 2005. A test of the biodiversity-stability theory: meta-analysis of tree species diversity effects on insects pest infestations, and re-examination of responsible factors. Ecol. Stud. 176: 235-262.

Kabzems, R., A.L. Nemec and C. Farnden. 2007. Growing trembling aspen and white spruce intimate mixtures: early results (13-17 years) and future projections. BC J. Ecosys. Manage. 8: 1-14.

Laquerre, S., A. Leduc and B.D. Harvey. 2009. Augmentation du couvert en peuplier faux-tremble dans les pessières noires du nordouest du Québec après coupe totale. Ecoscience 16: 483-491.

Lavoie, S., J.-C. Ruel, Y. Bergeron and B.D. Harvey. 2012. Windthrow after group and dispersed tree retention in eastern Canada. For. Ecol. Manage. 269: 158-167.

MacDonald, G.B. 1995. The case for boreal mixedwood management: An Ontario perspective. For. Chron. 71: 725-734.
MacDonald, G.B. and D.J. Thompson. 2003. Responses of planted conifers and natural hardwood regeneration to harvesting, scalping, and weeding on a boreal mixedwood site. For. Ecol. Manage. 182: 213-230.

MacIsaac, D.A. and R. Krygier. 2009. Development and long-term evaluation of harvesting patterns to reduce windthrow risk of understorey spruce in aspen - white spruce mixedwood stands in Alberta, Canada. Forestry, 82: 323-342.

MacPherson, D.M., V.J. Lieffers and P.V. Blenis. 2001. Productivity of aspen stands with and without a spruce understorey in Alberta's boreal mixedwood forests. For. Chron. 77: 351-356.

Man, R. and V.J. Lieffers. 1999. Are mixtures of aspen and white spruce more productive than single species stands? For. Chron. 75: 505-513.

Man, R., G.J. Kayahara, J.A. Rice and G.B. MacDonald. 2008. Eleven-year responses of a boreal mixedwood stand to partial harvesting: light, vegetation, and regeneration dynamics. For. Ecol. Manage. 255: 697-706.

Matthews, J.D. 1989. Silvicultural Systems. Clarendon Press, Oxford, UK

Milliken, G.A. and D.E. Johnson. 2002. Analysis of messy data. Vol. 3: Analysis of covariance, Chapman and Hall/CRC Press, Boca Raton, FL.

Mitchell, S.J. 2013. Wind as a natural disturbance agent in forests: A synthesis. Forestry 86: 147-157.

Nyland, R.D. 2002. Silviculture: Concepts and Applications. $2^{\text {nd }}$ ed. Waverland Press, Inc., Long Grove, IL.

Perala, D.A. 1990. Quaking aspen - Populus tremuloides Michx. In: R.M. Burns and B.H. Honkala (eds.). Silvics of North America. pp. 555-569. USDA For. Serv. Agric. Handb. No. 654, vol. 2. Hardwoods. Washington, DC.

Pothier, D., R. Doucet and J. Boily. 1995. The effect of advance regeneration height on future yield of black spruce. Can. J. For. Res. 25: 536-544.

Pothier, D., F. Raulier and M. Riopel. 2004. Ageing and decline of trembling aspen stands in Quebec. Can. J. For. Res. 34: 1251-1258.

Prévost, M. and D. Pothier. 2003. Partial cuts in a trembling aspen - conifer stand: Effects on microenvironmental conditions and regeneration dynamics. Can. J. For. Res. 33: 1-15.

Prévost, M. and J. DeBlois. 2014. Shelterwood cutting to release coniferous advance growth and limit aspen sucker development in a boreal mixedwood stand. For. Ecol. Manage. 323: 148-157.

Prévost, M. and D. Dumais. 2014. Shelterwood cutting in a boreal mixedwood stand: 10-year effects of the establishment cut on growth and mortality of merchantable residual trees. For. Ecol. Manage. 330: 94-104.

Prévost, M., D. Dumais and D. Pothier. 2010. Growth and mortality following partial cutting in a trembling aspen - conifer stand: results after 10 years. Can. J. For. Res. 40: 894-903.

Prévost, M., D. Dumais and J. DeBlois. 2016. Morphological response of conifer advance growth to canopy opening in mixedwood stands, in Quebec, Canada. Trees 30: 1735-1747.

Riopel, M., J. Bégin and J.-C. Ruel. 2010. Probabilités de pertes de tiges individuelles, cinq ans après des coupes avec protection des petites tiges marchandes, dans des forêts résineuses du Québec. Can. J. For. Res. 40: 1458-1472.

Ruel, J.-C., P. Raymond and M. Pineau. 2003. Windthrow after shelterwood cutting in balsam fir stands. North. J. For. Res. 20: 513.

Ruel, J.-C., D. Fortin and D. Pothier. 2013. Partial cutting in oldgrowth boreal stands: An integrated experiment. For. Chron. 89: 360-369.

Ruel, J.-C., C.P. Quine, S. Meunier and J. Suarez. 2000. Estimating windthrow risk in balsam fir stands with the ForestGales model. For. Chron. 76: 329-335. 
Saucier, J.-P., P. Grondin, A. Robitaille, J. Gosselin, C. Morneau, P.J.H. Richard, J. Brisson, L. Sirois, A. Leduc, H. Morin et al 2009. Écologie forestière. In : Ordre des ingénieurs forestiers du

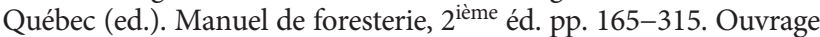
collectif, Éditions Multimondes, Québec, QC.

Schier, G.A. 1973. Origin and development of aspen root suckers. Can. J. For. Res. 3: 45-53.

Schier, G.A. and A.D. Smith. 1979. Sucker regeneration in a Utah aspen clone after clearcutting, partial cutting, scarification and girdling. USDA For. Serv. Res. Note INT-253.

Smith, D.M., B.C. Larson, M.J. Kelty and P.M.S. Ashton. 1997. The Practice of Silviculture: Applied Forest Ecology. th $^{\text {th }}$ ed. John Wiley \& Sons Inc. New York, NY.

Su, Q., T.D. Needham and D.A. MacLean. 1996. The influence of hardwood content on balsam fir defoliation by spruce budworm. Can. J. For. Res. 26: 1620-1628.

Tappeiner, J.C. 1971. Invasion and development of beaked hazel in red pine stands in northern Minnesota. Ecol. 52: 514-519.
Thorpe, H.C., S.C. Thomas and J.P. Caspersen. 2008. Tree mortality following partial harvests is determined by skidding proximity. Ecol. Appl. 18: 1652-1663.

Urgenson, L.S., C.B. Halpern and P.D. Anderson. 2013. Level and pattern of overstory retention influence rates and forms of tree mortality in mature, coniferous forests of the Pacific Northwest, USA. For. Ecol. Manage. 308: 116-127.

Westfall, P.H. 1997. Multiple Testing of General Contrasts Using Logical Constraints and Correlations. J. Am. Stat. Ass. 92: 299-306. Westfall, P.H., R.D. Tobias and R.D. Wolfinger. 2011. Multiple Comparisons and Multiple Tests Using SAS (2 ${ }^{\text {nd }}$ ed.). SAS ${ }^{\circ}$ Press, Cary, NC.

Winer, B.J. 1971. Statistical principles in experimental design $2^{\text {nd }}$ ed. New York, McGraw-Hill. 